\title{
Fluid Inclusions Usage for Assessing Oil Migration in Duhok, North Iraq
}

\author{
Salih Muhammad Awadh ${ }^{*}$, Thamer K. Al-Ameri ${ }^{1}$, Sahar Y. Jassim¹, Mehmet S. Bayraktutan ${ }^{2}$ \\ ${ }^{1}$ Earth Science Department, College of Science, University of Baghdad, Baghdad, Iraq; ${ }^{2}$ Botas International Limited, Cyhan, Adana, Turkey \\ Email: *Salihauad2000@yahoo.com
}

Received October $12^{\text {th }}, 2009$; revised October $28^{\text {th }}, 2010$; accepted November $1^{\text {st }}, 2010$

\begin{abstract}
Studies of primary and secondary fluid inclusions were done on epigenetic barite samples collected from carbonates of Lower part of Sarmord Formation (Lower Cretaceous) and Aqra-Bekhme Formations (Upper Cretaceous) in Duhok, north Iraq. Lead isotopes composition in galena which associated barite that contained fluid inclusions helped the identification two events of fluid inclusions. These fluid inclusions contain brine water and hydrocarbons. Primary and secondary fluid inclusions in barite as well as lead isotopes composition in galena helped the interpretation of oil migration history and the pathway of oil migration. Ages of galena are syngronous with the events of oil and water trapping as inclusions within barite, and hence the interpreted galena generation could be assigned to the fluid inclusions age. Accordingly, the events are two phases of early and late generations that correspond to 120 m.y. and 30 m.y. respectively. Correlation with 10 PetroMod basin modeling of the generated oil from the Jurassic and Lower Cretaceous Formations fitted with the event of early galena generation, whereas the oil migration started before 70 m.y. and continued to 30 m.y. ago. Palynomorphs study confirmed that the oil in source rocks is similar with the migrated oil.
\end{abstract}

Keywords: Fluid Inclusions, Oil Migration, Oil History, Paragenetic Sequence, Iraq

\section{Introduction}

Primary migration is the process by which hydrocarbons are expelled from the source rock into an adjacent permeable carrier bed. Oil phase migration means most hydrocarbons probably are expelled from the source rock as liquids. The expulsion of the oil out of the source rock is a dynamic process driven by the oil generation itself. Secondary migration is the movement of hydrocarbons along a "carrier bed" from the source area to the trap. Driving migration forces is that force acts vertically and is proportional to the density difference between water and the hydrocarbon so it is stronger for gas than heavier oil [1].

Fluid inclusions are microscopic traces in minerals that were in the fluid state at the time of entrapment. They may exist as vapor, liquid or solid or any combination thereof. The suggestion that hydrocarbon-rich, primordial fluid inclusions concentrated in the basal lithosphere are released and migrate from time to time on pathways opened tectonically suggests massive inorganic petroleum discharges. This suggested scenario for the origin of petroleum is based on the theory that hydrocarbon accumulations in sedimentary basins [2]. Fluid inclusions could be formed in sedimentary rocks such as limestone by crystallization which chronogical syngronous with the deposition while crystallization enough developed post deposition and trapped fluids that are passing through them and reflect geothermometry during the time of trapping. Accordingly, diagenetic fluid inclusion could illustrate how thermal maturation of the enclosed organic maters, and hence combined with maturation modeling to elucidate the diagenetic history of the basin. The most petroleum systems in Iraq are the Jurassic, Cretaceous and Tertiary petroleum system. The know extent of Triassic petroleum system is confined to the small area $\mathrm{N}$ Iraq which is extending into part of NE Syria N Iraq and SE Turkey [3]. The oil generation of M. Jurassic source rocks started in S Iraq and Kirkuk Empayment during the Oligocene and that oil then migrated towards Salman Zone in south of Iraq and towards the Mosul High in the north [4].

This work is based on reported fluid inclusions from fewer localities of the ore deposits [5]. They are located in Banik which lies $25 \mathrm{~km}$ northeastern Zakho, and the same distance of south Turkey border (Figure 1).

Aims of this work are to draw a historical scenario of oil migration via the finding of fluid inclusion generation 

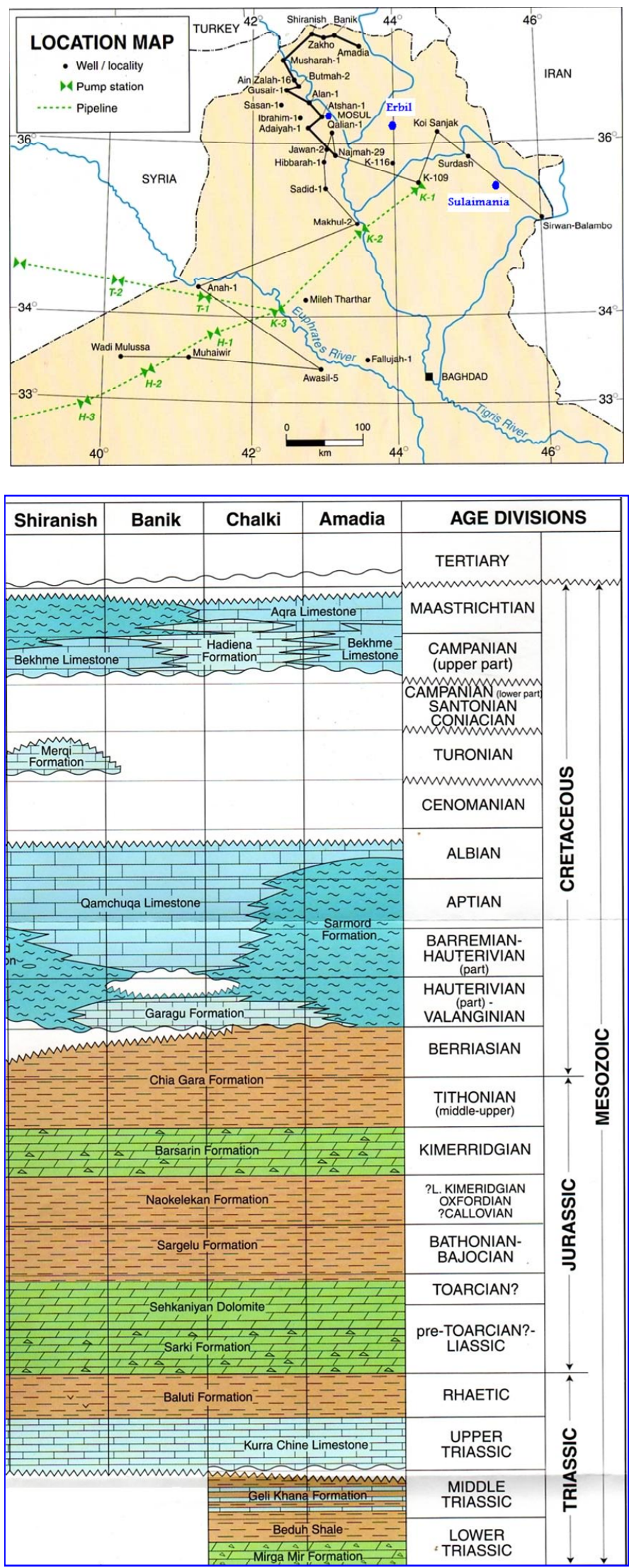


\section{KEY TO LITHOLOGICAL AND BOUNDARY SYMBOLS}
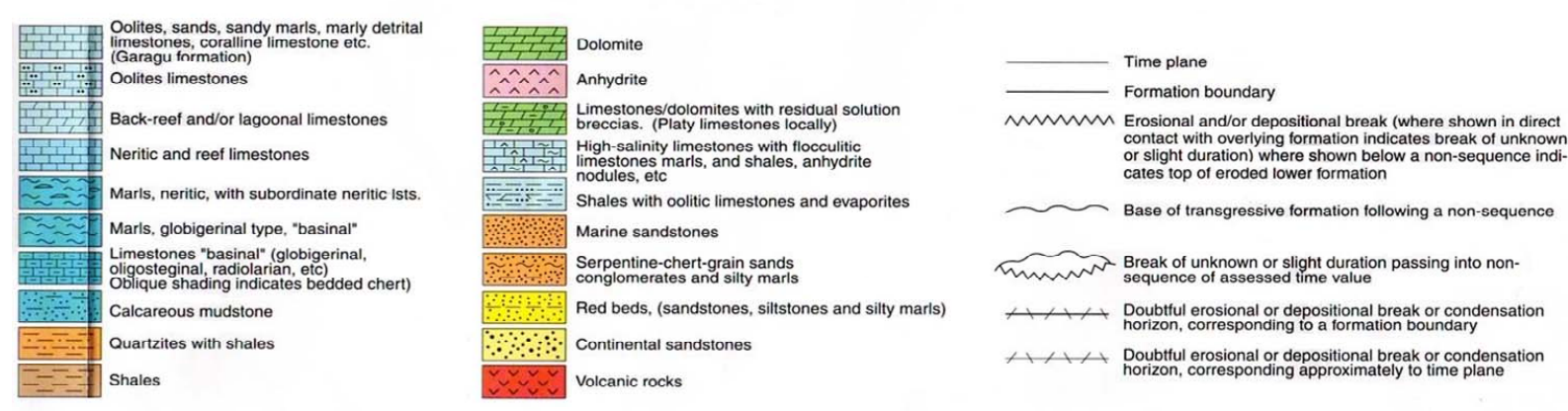

NOTE: Where time planes are shown in coincidence with formation boundaries, is generally

to be accepted as a convenient approximation unsupported by precise fossil evidence.

Figure 1. Location map and stratigraphic secsessionof the Mesozoic rock units in Northern Iraq (After Bellen et al., 2005).

relations to the generation and migration of hydrocarbons in North Iraq, and to point at the pathway of oil migration.

\section{Methods}

To achieve this work, Field work in the north Iraq was done in purpose to analysis the sedimentary basin and the structure effects; thereafter, mineral deposits (barite and galena) which have known origin (magmatic solution mixed with oilfeild brine water) [5] were sampled. Microthermometric method is applied in simplified way for detecting oil inclusions and determining their density; therefore Ultraviolet (UV) fluorescence microspectrophotometry was processed for measuring fluorescence spectra of oils inclusions in individual micro-sized inclusions, then oil inclusions specific gravity (API ${ }^{\circ}$ ) compared with known $\mathrm{API}^{\circ}$ gravity of North Iraqi oil. Interpretation of UV fluorescence of oil inclusions in an unknown sample is made by comparison with the fluorescence spectra of the known oil composition. This method is non -destructive process and allows the quality of oils in the undrilled basin to be determined by analyzing outcrop samples containing oil-bearing inclusions. Microthermometry and microspectrometry analyses were done in London University. The relative chronological relationships also were determined based on paragenetic sequence analyses of mineralzation.

Finally, and in purpose to determine the absolute ages, lead isotopes in galena were measured, so the two stage methods had been applied to the model ages. This analysis had been carried out at the Czech Geological Survey in Prague.

\section{Stratigraphic Setting}

The stratigraphic succession in north Iraq Amadia, Chalki, Banik (the study area) and Shiranish is illusrated in Fig- ure 1. In the study area, the lower part of Sarmord Formation (Hawterivian-Barremian) of Lower Cretaceous appears as tongue within bottom of Qamchuqa Limestone Formation (Barremian-Albian); or on fact, the Qamchqa conformably overlies Sarmord Formation Figure 1. In Banik area, the contact between Qamchqa and the bottom of the Aqra-Bekhme Limestone Formation (U.CapanianU.Maastrachtian) is unconformable [6]. The Aqra-Bekhme Limestone Formation is recommended to use when Aqra Limestone is superimpose directly upon the Bekhme Limestone Formation without intervention of Shiranish which is mainly consisted of marly limestone of deep basinal facies. The Aqra-Bekhme Limestone Formation emplacement conformably under Shiranish Formation (U.Capanian-U.Maastrachtian); then it covers Hadiena Formation (Campanian). Shiranish Formation at the top of the stratigraphic succession has eroded in Banik area (Figure 1). The top of Shiranish Formation represents unconformable surface with the Tartiary (Figure 1).

\section{Fluid Inclusions}

Specific tests on fluid inclusions were done in order to study the processes involving migration and accumulation of oil. Fluid inclusions within epigenetic barite originated by mixing of magmatic solution and oilfield brine water were investigated microscopically for determining the oil events. Oil migration mostly takes place as one or more separate hydrocarbons phases (gas or liquid depending on pressure and temperature conditions); there is also minor dissolution in water of methane and short chain hydrocarbons [1]. Microthermometry revealed both primary and secondary fluid inclusions are there. Primary fluid inclusions appeared including liquid oils, brine water and sometime bitumen (Figure 2(a)); the same contents were also found (Figure 2(b)).

Ultraviolet (UV) fluorescence microspectrophotometry displayed two fluorescence colors yellow and brown; the 
yellow fluorescence color emitted from both primary and secondary fluid inclusions of heavy oil (Figures 3(a), (b)) that had been trapped within early generated barite (Table 1). The Secondary inclusions Figure 3(b) have 1718.8 API (Table 1) indicate a heavy oil has been migrated during period of post depositional of the early generated barite which has older than of 120 m.y. (Table 2); whereas the primary oil inclusions Figure 3(a) that characterized by API ranged from $11.4^{\circ}$ to $20.2^{\circ}$ (Table 1) are also heavy oil that had migrated before the late generated barite deposited. The API gravity of these oil inclusions is the same of those from sargelu Formation which range from $13.3^{\circ}$ to $42^{\circ}$ (Jassim and Goff, 2006).

The brown fluorescence color emitted from secondary oil inclusions which existing within late generated barite (Figure 3(c)) which is formed epigenetically within Aqra -Bekhme Formation indicates a very heavy oil have API from 4.5 to 8.3 (Table 1). This means that the oil inclu sions reach Aqra-Bekhme Formation after generation the early barite. The API gravity increases as a result of maturation, thus that low value of API may be indicated the Paleozoic source rocks.
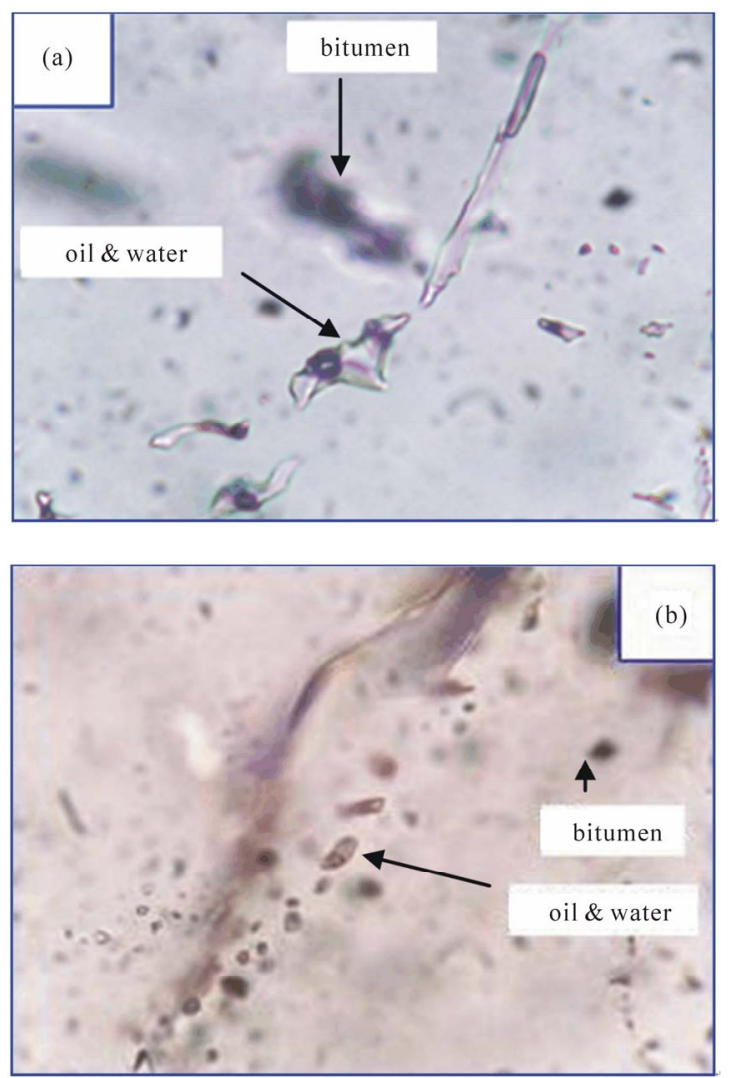

Figure 2. Primary fluid inclusions (a) and secondary fluid inclusions (b) contain oil and bitumen mixed with oilfield brine water.

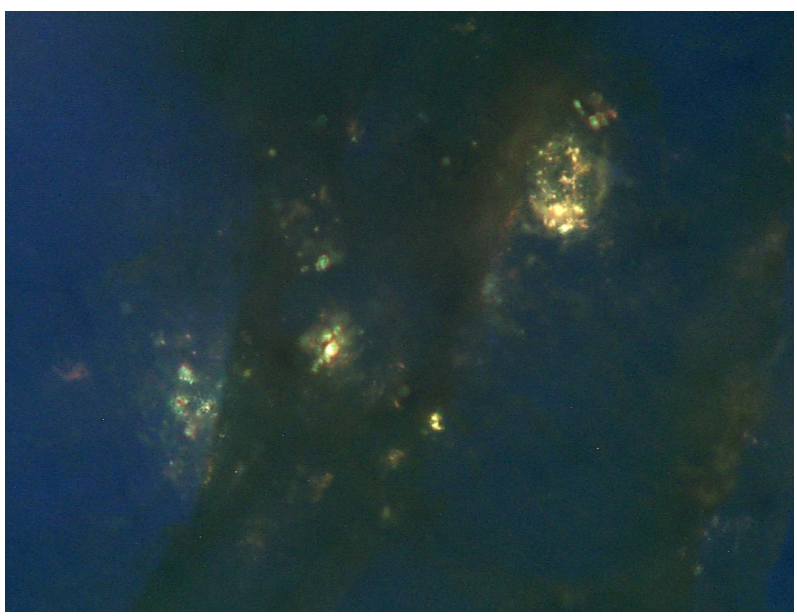

(a)

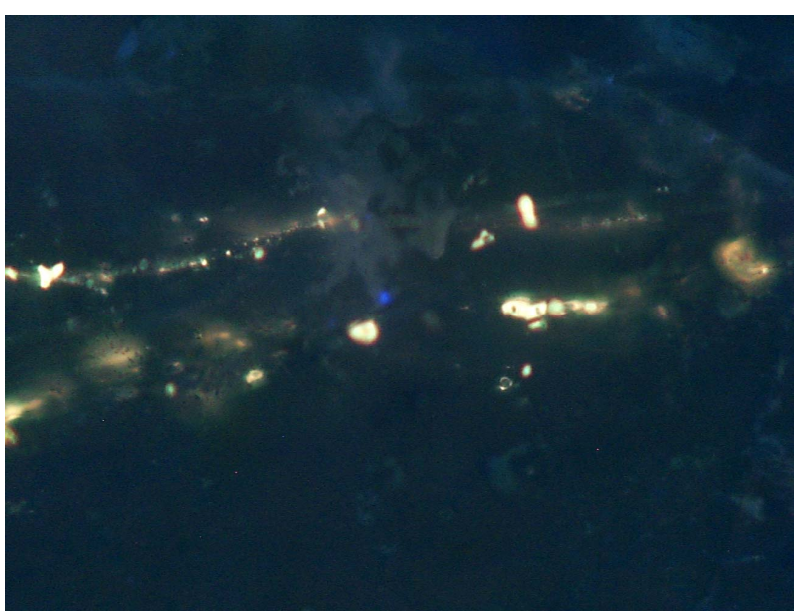

(b)

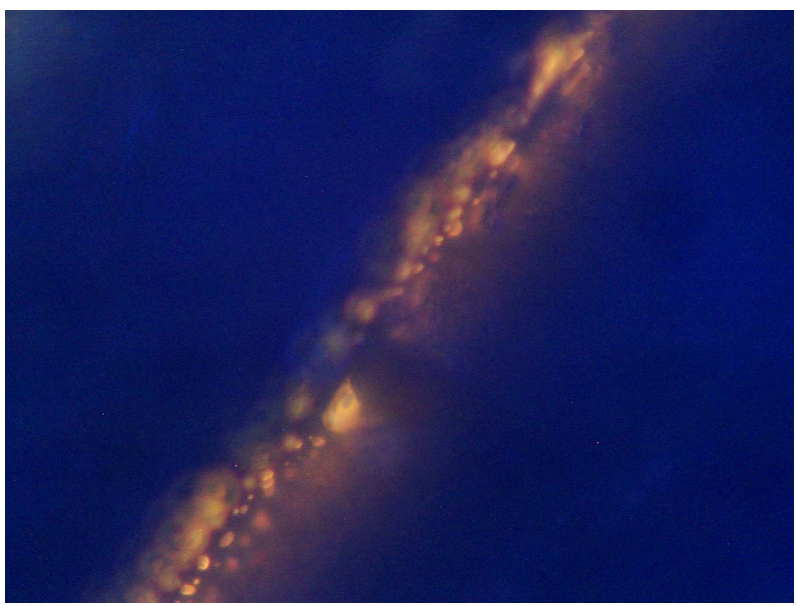

(c)

Figure 3. Yellow color of Ultra violet fluorescence of primary and secondary oil fluid inclusions ((a) and (b) respectively) of heavy oil; and brown color (c) of secondary oil fluid inclusions of very heavy oil. 
Table 1. Fluid inclusions data of the early and late generated barite; API: American Petroleum Institution. Samples (1 to 10 BU) were collected from Lower Sarmord Formation, whereas samples 1 to 4Lef were collected from Aqra-Bekhme Formation.

\begin{tabular}{|c|c|c|c|c|c|}
\hline Sample No. & $\begin{array}{c}\text { Barite } \\
\text { generation }\end{array}$ & $\begin{array}{c}\text { Fluorescence } \\
\text { color }\end{array}$ & Host, type & API $^{\circ}$ Gravity & Type of oil \\
\hline $1 \mathrm{BU}$ & Early & yellow & barite, secondary & 18.6 & Heavy oil \\
\hline $2 \mathrm{BU}$ & Early & yellow & barite, secondary & 17.0 & Heavy oil \\
\hline 3BU & Early & yellow & barite, secondary & 18.1 & Heavy oil \\
\hline $4 \mathrm{BU}$ & Early & yellow & barite, secondary & 18.1 & Heavy oil \\
\hline $5 B U$ & Early & yellow & barite, secondary & 18.8 & Heavy oil \\
\hline $6 \mathrm{BU}$ & Early & yellow & barite, secondary & 17.5 & Heavy oil \\
\hline $7 \mathrm{BU}$ & Early & brown & barite, secondary & 5.2 & Very heavy oil \\
\hline $8 B U$ & Early & brown & barite, secondary & 8.3 & Very heavy oil \\
\hline $9 B U$ & Early & brown & barite, secondary & 6.0 & Very heavy oil \\
\hline $10 \mathrm{BU}$ & Early & brown & barite, secondary & 4.5 & Very heavy oil \\
\hline 1Lef & Late & yellow & barite, primary & 11.4 & Heavy oil \\
\hline 2Lef & Late & yellow & barite, primary & 20.2 & Heavy oil \\
\hline 3Lef & Late & yellow & barite, primary & 11.5 & Heavy oil \\
\hline 4Lef & Late & yellow & barite, primary & 14.9 & Heavy oil \\
\hline
\end{tabular}

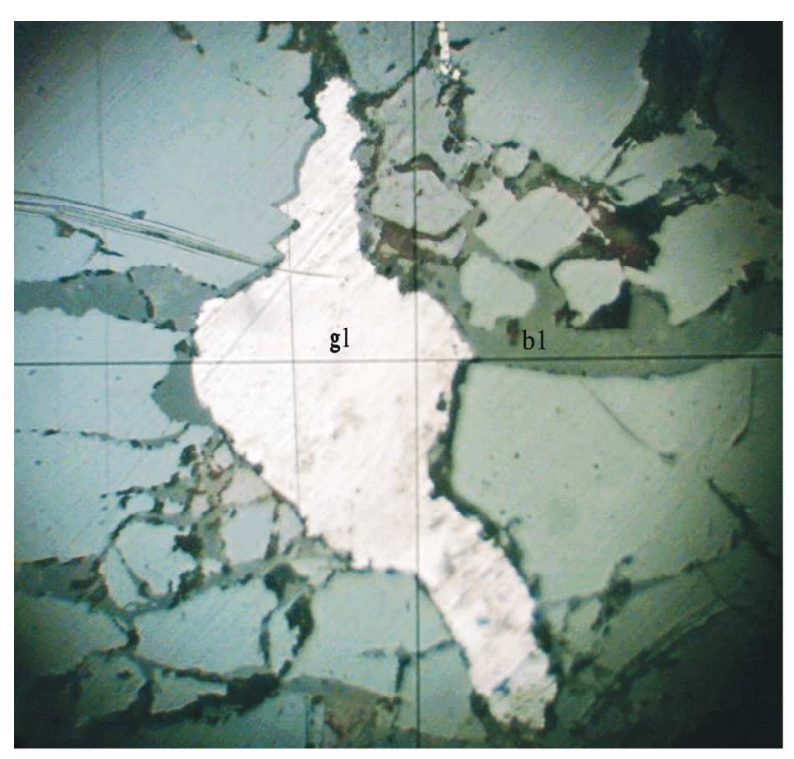

(a)

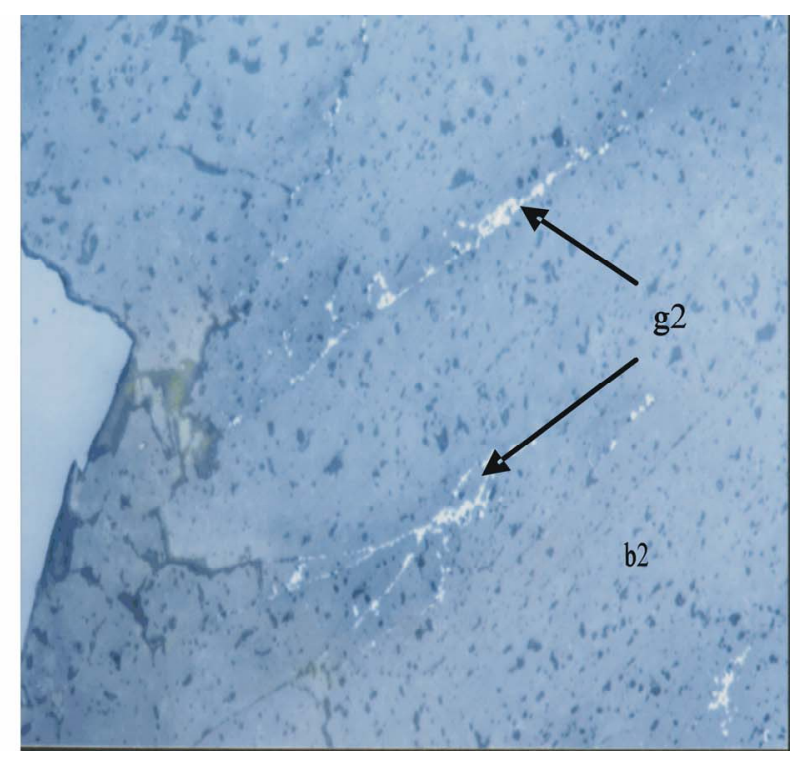

(b)

Fiqure 4. (a) Early generated galena (g1) cuts early generated barite (b1); galena (120 m.y. is older than barite), therefore the oil inclusions in this barite is older than 120 m.y.; (b) Late generated galena of 30 m.y. (white veinlets, g2) deposited along cleavage plane of late generated barite (b2).

\section{Paragenetic Sequence and Oil History}

Paragenetic sequence of mineralization hosted in Lower part of Sarmord Formation (Lower Cretaceous of about 134 m.y.) and Aqra-Bekhme Formation (Upper Cretaceous) was analyzed (Table 2) depending on the field observation as well as the petrographic study which had curried on both thin and polished sections. It was found two generations of both barite and galena. Theses ore deposits had been epigenetically deposited. The early generated barite was found within the Lower part of Sarmord formation; this means that the early generated barite is younger than country rocks which have Lower Cretaceous age; whereas the late generated barite is younger than Upper Creta- 
ceous because it was found epigenetically deposited within Aqra-Bekhme Formation (Upper Cretaceous). Early generated galena (120 m.y.) was crosscutting early generated barite (Figure 4(a)); therefore the age of early generated barite ranges from 134 to 120 m.y. (Table 2); accordingly the primary oil fluid inclusions that existed within the early generated barite had been trapped within period extended between 134 and 120 m.y.; whereas the secondary oil fluid inclusions indicate the continuity oil migration. This means the oil had started migration away from source rocks before 130 million years ago. The late generated galena (30 m.y.) was found within Aqra-Bekhme Formation; it also epigenetically deposited but along cleavage cracks of late generated barite (Figure 4(b)); therefore the age of the late generated barite is estimated to extend from younger than 70 to older than 30 m.y. (Table 2).

\section{Correlation between South and North Iraqi oil (Migration and Accumulation)}

The driven force that caused the movement of mineralizing fluids (oilfield brine water mixing with hydrothermal of magmatic solutions) is Lower Cretaceous Orogeny and Alpine orogeny in Paliocene [5]. The deep water facies of Shiranish Formation that emplaced upon the reef shoal water reef of Aqra-Bekhme Formation introduced a reliable evidence of beginning crustal extention and rifting [5]. The lower Cretaceous orogeny permitted the oil migration from the source rocks of the middle Jurassic. This suggestion is supported by the absolute age of early generated galena which is $120 \mathrm{~m} . \mathrm{y}$.

In comparison with performed software 1D PetroMode of petroleum system modeling on oil wells in Iraq [7], the generation of petroleum in the strata of this pe- troleum system is of two main phases (Figure 5). The first phase was the petroleum generation from the Jurassic
Formations of Sargelu, Najmah (Naukelekan and Barsarin equivalent in The North of Iraq) and Sulaiy (Chia Gara Formation equivalence in the North of Iraq) that begun in the late Cretaceous 90-80 million years ago and ended their $100 \%$ transformation ratios of their generation potential during lower Tertiary 35 million years ago except Sulaiy that extend to 10 million years ago. These generated hydrocarbons have charged the structural traps that formed during Cretaceous time. These formations were deposited in dysoxic-anoxic environment of marine carbonate that have total organic carbon of $0.5-8 \mathrm{wt} \%$, and temperature effect of $140-120^{\circ} \mathrm{C}$ and is consistent with the $100 \%$ hydrocarbon efficiency.

Accordingly, the fluid inclusions that have been existed in the late generated barite within Aqra-Bekhme Formation coincide with the generation time of the Sargelu and Naukelekan Formations (Jurassic and Lower Cretaceous source rocks). These hydrocarbons with the associated brine water moved and migrated upward to their accumulation sites with time range of 90-30 m.y. in the mainly Upper Cretaceous and hence, they had been trapped as fluid inclusions along their migration pathways. Two stages of fluid inclusions of 120 and 30 m.y. are within generation, migration and accumulation of the hydrocarbon from the Sargelu and Naukelekan Formations source rocks that accumulated in the reservoirs of the Upper Cretaceous and Tertiary toward south and south east of Zakho. During migration, fluid inclusions were trapped in the Lower Cretaceous Sarmord Formation and the Upper Cretaceous Shiranish Formation equivalence of Aqra-Bekhme Formation (Figure 6). Oil yielded of the source rocks in north of Zakho and migrated upward has been lost by seepage on the surface within Northern Thrust Zone because no Tertiary seal therein.

Table 2. The paragenetic sequence of fluid inclusions bearing minerals and hydrocarbon events.

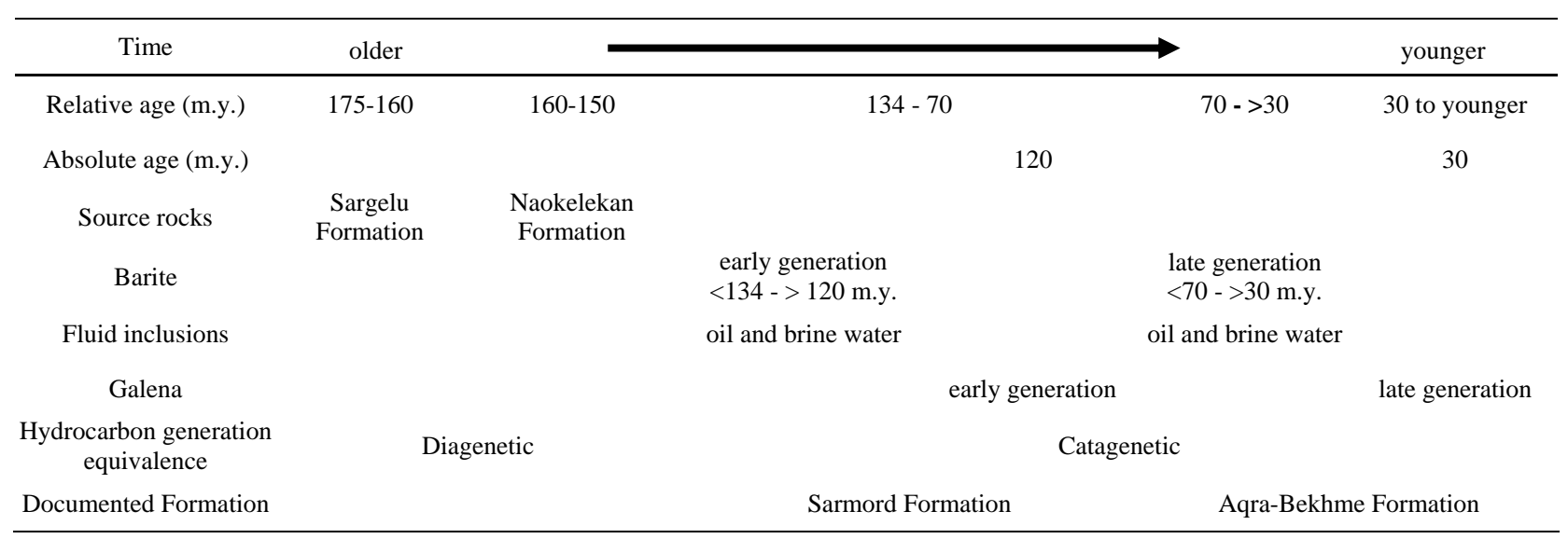




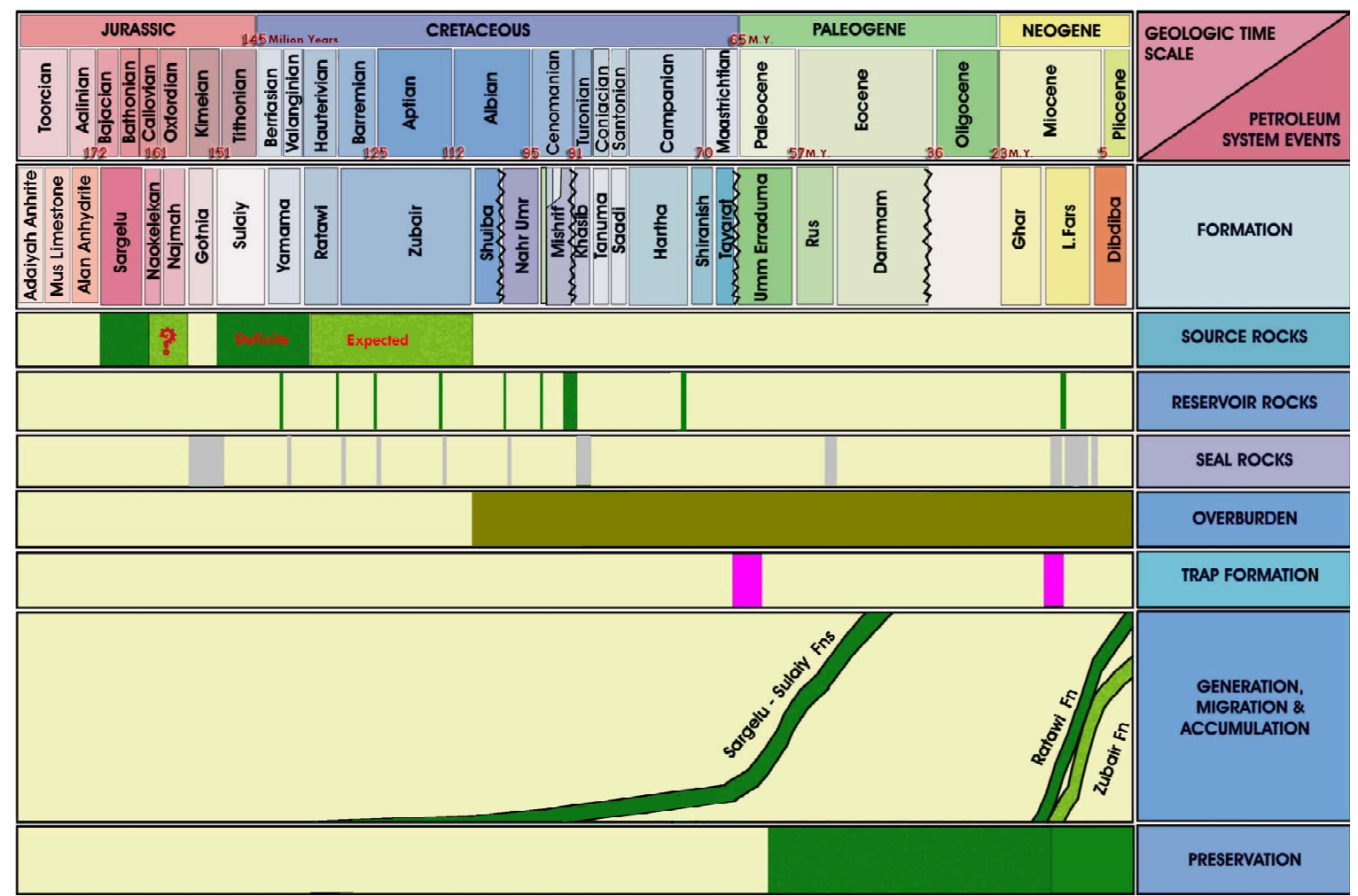

Figure 5. Events chart of hydrocarbon in Iraq showing hydrocarbon generation, migration and accumulation southern Iraq, (After Al-Ameri et al., 2009) comparable to the fluid inclusion trapping ages. The blue line was adding by this study so as to display the hydrocarbon generation, migration and accumulation of the Sargelu Formation in the north of Iraq.

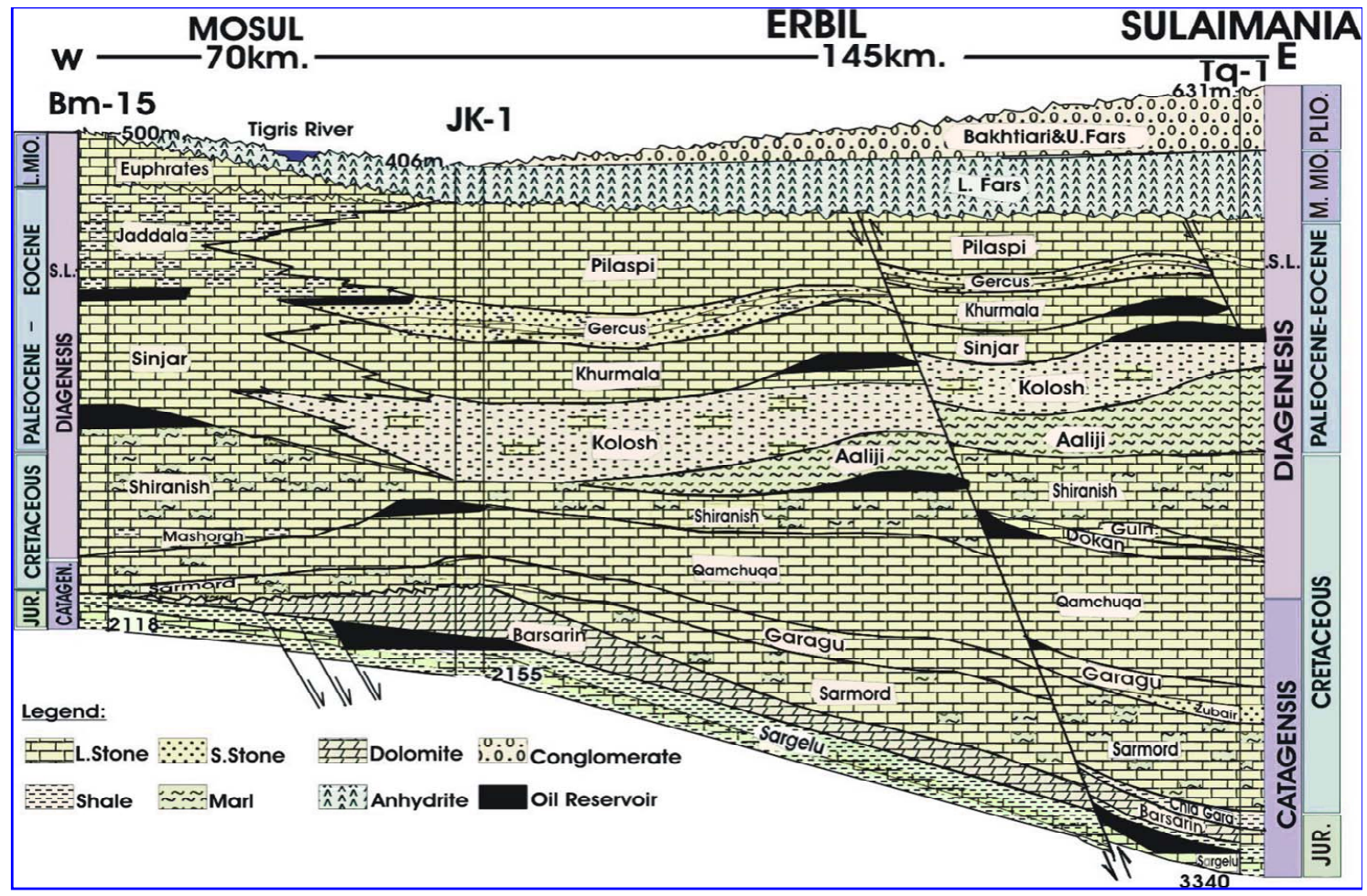

Figure 6. Oil accumulation sites in North of Iraq, (After Al-Ameri et al., 2008); so as to see the location of this cross section, see Figure 1. 


\section{Discussion and Conclusions}

The oil fluid inclusions and pargenetic sequence of mineralization clearly explained that the oil had been migrated from source rocks of Sargelo and Naokelekan formations (M. Jurassic) and Chia Gara Formation (U. Jurassic to L. Cretaceous). This event had been documented in the early generated barite within Sarmord Formation (L. Cretaceous); and it is trapped after the diagenesis of hydrocarbon generation. Fluid inclusions in the late generated barite documented within Aqra-Bekhme Formation considered as fingerprint of catagenetic hydrocarbon generation and this also has been documented within Aqra-Bekhme Formation.

As the organic matter transforms into oil, this leadbearing kerogen turns into liquid. The fluid pressure of the oil within the black shales can become high enough to produce micro fractures in the rocks. Once the micro fractures form, the oil is squeezed out and the source rock collapses.

By comparing the fluorescence properties of inclusions oils and reservoir oils, the history of oil migration in petroleum basins can be reconstructed. Many evident from this work are concluded as following:

1) Two types of oil were determined; these are heavy and very heavy oil.

2) The oil generation started before 134 million years ago from source rocks (Sargelu, Naokelekan and Chia Gara Formations).

3) The oil fluid inclusions in barite drown the pathway of oil that migrated vertically and horizontally. The oil that migrated upward had lost, because the absence of Tertiary units, whereas the oil migrated south and south east ward from high pressure to the low pressure regions was been entrapping by the structural and lithological traps (Figure 6).

4) Convergent plates yield a compression stress styles such as thrust faults, folds, faulted folds. The oil migration explained above happened syngronous with the orogeny; subduction between Arabian plate and both Turkey and Iranian plates started at the end of Jurassic (Late Tithonian) (Numan, 2001). The late Tithonian is about 145 million years ago; this age appears to be fit with result of fluid inclusions entrapment of diagenetic oil.

5) The oil migration continued upward along faults and fractures and through porous formations which are considered as suitable pathways; this is documented by the secondary fluid inclusions.
6) The migrated oil had reached the Aqra-Bekhme Formation within the range of 70 to 30 million years ago on its pathway toward the new structural trap that may had been formed within Tertiary.

7) The Sargelu Formation of Middle Jurassic (167 m.y.) appears to be the main source rocks which has TOC of 1 to $17 \mathrm{wt} \%$. Suitable source rocks have TOC (total organic content) ranges from 3 to $10 \%$ [8]. The organic matters of Sargelu Formation are comparable with the biomarker of the oil accumulated in the Cretaceous oil reservoirs inclusions and seeps in North Iraq [9].

The extracted palynomorphs from Upper Jurassic-Lower cretaceous source rocks appeared as similar as with the extracted palynomorphs from the migrated oil.

\section{REFERENCES}

[1] J. M. Hunt, "Petroleum Geochemistry and Geology,” W. H. Freeman and Company, 1996, p. 405.

[2] V. A. Krayushkin, "Genuine Origin, Structure, Value and Distribution of World's Petroleum Potential,” Georesources, Vol. 3, No. 4. 2000, pp. 14-18.

[3] S. Z. Jassim and G. C. Goff, “Geology of Iraq,” Printed in the Czech Republic, p. 341.

[4] J. K. Pitman, D. Steinshouer and M. D. Lewan, "Petroleum Generation and Migration in the Mesopotamian Basin and Zagros Fold Belt of Iraq: Results from BasinModeling Study,” Geo Arabia, Vol. 9, No.4, 2004, pp. 41-71.

[5] S. M. Awadh, R. H. Habib and K. Al-Bassam, "Geneses of the Zinc-Lead-Barite Deposits in the Northern Iraq: Ore Mineralogy, Geochemistry, Fluid Inclusions, Lead Isotopes and Sulfur Isotopes Implicatiuons,” Dirasat, Vol. 35, No. 2, pp. 96-110.

[6] V. R. C. Bellen, H. V. Dunnington, R. Wetzel and D. M. Morton, "Stratigraphic Lexicon of Iraq," Lexique Stratigraphique Internationl, Asie (Iraq), Printed by permission of CNRS, France, p. 293.

[7] T. K. Al-Ameri, A. Al-Khafaji and J. Zumbergo, "Petroleum System of the Mishrif in the Ratawi, Zubair, Rumaila North and Rumala South Oil Fields, Southern Iraq," Geo Arabia, Vol. 14, No. 4, 2009, pp. 91-108 .

[8] V. V. Palciauskas, "Primary Migration of Petroleum," American Association of Petroleum Geologists, Vol. 1, No. 3, 1991, pp. 13-22.

[9] T. K. Al-Ameri, A. Al-Ahmed, J. Zumbergo and J. Pitman, "Hydrocarbon potential of Middle Jurassic Sargelu Formation, Zagros Fold Belt, Northern Iraq," Geo Arabia, Vol. 13, No. 1, p. 111 (poster). 